\title{
Sexual reproduction efficiency and genetic diversity of endangered Betula humilis Schrk. populations from edge and sub-central parts of its range
}

\author{
Agnieszka Chrzanowska • Katarzyna A. Jadwiszczak • Stanisław Kłosowski • \\ Agata Banaszek • Oleg V. Sozinov
}

Received: 11 May 2015/ 000000 / Accepted: 2 May 2016/Published online: 28 June 2016

(C) The Author(s) 2016. This article is published with open access at Springerlink.com

\begin{abstract}
Outcrossed mating systems play a very important role in the persistence of endangered, selfincompatible plants such as shrub birch, Betula humilis Schrk. The goal of this study was to estimate, for the first time, the effectiveness of sexual reproduction in threatened edge and sub-central populations of shrub birch. The amplified fragment length polymorphism (AFLP) method revealed that all of the individuals at each locality had different genotypes. The matrix incompatibility count (MIC) suggested that the effectiveness of recombination was similar among all the populations of shrub birch under study. However, taking into account the greater germination ability of seeds in subcentral populations, we conclude that sexual reproduction in those populations can be more efficient. The germination capacity of seeds depends on their mass, which was significantly lower in dry or more shaded sites compared to wet or more exposed sites. Nonsignificant results of multiple regression models suggest that chemical parameters of the habitat $\left(\mathrm{pH}, \mathrm{EC}, \mathrm{NH}_{4}{ }^{+}\right.$,
\end{abstract}

A. Chrzanowska $(\square) \cdot$ K. A. Jadwiszczak $\cdot$ A. Banaszek Institute of Biology, University of Białystok, Ciołkowskiego 1J, 15-245 Białystok, Poland

e-mail: maga.chrzanowska@gmail.com

S. Kłosowski

Department of Environment Protection and Modelling, The Jan Kochanowski University, Świętokrzyska 15, 25-406 Kielce, Poland

O. V. Sozinov

Department of Biology and Ecology, Yanka Kupala State University of Grodno, Ožeško 22, 230023 Grodno, Belarus
$\mathrm{PO}_{4}{ }^{3-}$ ) had no influence on the reproductive output of $B$. humilis. The discrepancy between the still quite substantial genetic diversity and the poor sexual reproduction in shrub birch populations can be explained by the production of a few phosphorus-rich seeds, insufficient time for a decrease in genetic variation in the disappearing part of the range or hybridization with close congeners.

Keywords AFLP B Betula humilis · habitat parameters · matrix incompatibility count $\cdot$ recombination . sexual reproduction

\section{Introduction}

In its updated Global Strategy for Plant Conservation, the Convention on Biological Diversity demanded protection for $60 \%$ of the world's plant species (Joppa et al. 2013). It is widely accepted that developing the most effective conservation strategies for endangered species requires knowledge of genetic resources and the mechanisms responsible for their distribution within species ranges (Rao and Hodgkin 2002). The primary distributions of species genetic diversity are the outcome of range contractions during the stadials of the Pleistocene glaciations and of expansions during the interstadials (Hewitt 1999; Petit et al. 2003). However, the patterns of genetic structuring within and between populations established after the glacial retreat have since been modified by the life history traits of species (e.g. mating system, clonal reproduction and seed dispersal - Glémin 
et al. 2006; Alsos et al. 2012; De Witte et al. 2012), the ongoing evolutionary processes that shape current populations (e.g. mutation, selection, genetic drift and gene flow-Mitton and Duran 2004; Jump et al. 2006; Jadwiszczak et al. 2012b) as well as fragmentation of habitats resulting mainly from anthropopression (Jump and Peñuelas 2006).

Among the biological characteristics of plant species, mating systems play an especially significant role in the persistence of populations because they shape genetic structure via the transmission of genes across generations, determine the rate of genetic diversity loss and influence the evolution of traits (Hamrick and Godt 1996; Neel et al. 2001; Glémin et al. 2006). Clonally reproducing self-incompatible plants seem to be particularly threatened due to the low number of genetically distinct individuals (genets) in a population, which diminishes the chances for conspecific pollination with compatible mates. In plant populations with incomplete reproductive barriers, the second danger is an increased probability of interspecific breeding with common congeners that could result in either the production of inviable seeds or the displacement of rare species by overdominant hybrid progeny (Nagamitsu et al. 2006). All of the above situations could drive small populations to extinction.

The purpose of this study was to determine the factors influencing the reproductive success and genetic diversity of populations of shrub birch, Betula humilis, located at the edge (Poland) and in sub-central (Belarus) parts of its range. Betula humilis is a much-branched shrub with dark brown bark covered with numerous white resin glands. Like other birches, this plant is light-demanding, and its growth depends on the intensity of solar radiation. The bushes are usually not higher than 1-2 $\mathrm{m}$, but they can reach a height of 3-4 $\mathrm{m}$ in heavily shaded positions. The species inhabits seven main types of habitats: Sphagnum moss-small sedge poor fens with a high contribution of bog species from the class Oxycocco-Sphagnetea, brown moss-small sedge subneutral fens with the highest number of richfen species from the class Scheuchzerio-Caricetea nigrae, brown moss-small sedge alkaline fens with species from the Caricion davalianae alliance, strongly degraded fens dominated by Urtica dioica and Galium aparine, spring mires with water rich in $\mathrm{Mg}^{2+}$ and $\mathrm{Ca}^{2+}$ ions, and alkaline fen meadows (Jabłońska 2012). Because drainage benefits the plant in some way, $B$. humilis can also be abundant in moderately or even intensively drained variants of natural habitats. The chemical properties of groundwater sampled in B. humilis populations are differentiated: $\mathrm{pH} 3.7-8$, 50-1,200 $\mu \mathrm{Sm} \cdot \mathrm{cm}^{-1} \mathrm{EC}, 5-130 \mathrm{mg} \cdot l^{-1} \mathrm{Ca}^{2+}, 0.5-20$ $\mathrm{mg} \cdot \mathrm{l}^{-1} \mathrm{Mg}^{2+}, 0-10 \mathrm{mg} \cdot \mathrm{l}^{-1} \mathrm{~N}_{-\mathrm{NH}_{4}}^{+}$and $0-0.65 \mathrm{mg} \cdot \mathrm{l}^{-1}$ $\mathrm{P}_{-} \mathrm{PO}_{4}{ }^{3-}$ (Jabłońska 2012).

Shrub birch is under strict protection in Poland, Germany, Ukraine and the Kaliningrad Oblast of northwestern Russia. In Poland, the number of populations has decreased approximately fourfold during the twentieth century (Załuski et al. 2014). In 2014, the species was also included on the list of rare and endangered species in Belarus (Calko 2014). Despite the contraction of the range of shrub birch, previous nuclear microsatellite analyses have revealed a still reasonably high level of intra-population genetic diversity, low to average inter-population differentiation and non-significant genetic differences between edge Polish and sub-central Belarusian populations (Jadwiszczak et al. 2011a,b). The distributions of chloroplast DNA and nuclear $A D H$ (alcohol dehydrogenase) gene haplotypes strongly imply that the study territory was populated through waves of migrations from distinct glacial refugia, so the substantial genetic diversity could have resulted from the formation of an admixture zone (Jadwiszczak et al. 2012a, 2015a,b). The shapes of the cpDNA and $A D H$ minimum spanning trees indicate a rapid increase in population size during recent expansions of the species' range and low or modest gene flow between contemporary populations (Jadwiszczak et al. 2012a, 2015b).

Like many rare species, $B$. humilis is a poor competitor, so it is more abundant in sites where other plants cannot develop, i.e. places with high concentrations of calcium ions and high water levels (Jabłońska 2006, 2012). However, little is known about the current evolutionary forces acting on shrub birch populations. The relatively low genetic diversity and significant differentiation among some of the smallest and most isolated populations from northern Poland suggest that they are subjected to strong genetic drift and limited gene flow (Jadwiszczak et al. 2011a). Additionally, selection may act against heterozygous genotypes in calcium-rich habitats, as a significant negative correlation was found between the observed heterozygosity of microsatellite loci and $\mathrm{Ca}^{2+}$ concentrations (Jadwiszczak et al. 2015b). To the best of our knowledge, there is no information in the literature on the effectiveness of sexual reproduction of B. humilis. Shrub birch is a monoecious, wind- 
pollinated and wind-dispersed species, and based on annual seed production (Załuski et al. 2014) and the substantial variation at microsatellite loci (Jadwiszczak et al. 2011a,b), it has been assumed that sexual reproduction is prevalent in populations located at the southwestern edge of the range. However, analysis of nuclear microsatellite genotypes has indicated that the species spreads only clonally in unfavourable habitats (Chrzanowska and Jadwiszczak 2015). Our aims were to: (1) study if flower and seed productions vary significantly among $B$. humilis populations in edge and subcentral parts of its range, (2) determine the relative importance of environmental conditions for the sexual reproduction of the species, and (3) investigate the relationships between sexual reproduction and genetic variation parameters. Genetic diversity in the populations studied was assessed using the amplified fragment length polymorphism (AFLP) method. Of eleven populations, nuclear microsatellites had previously been investigated at ten sites (Jadwiszczak et al. 2011a,b), but the AFLP method, which can discover hundreds of DNA loci throughout the whole genome, is a more effective tool than microsatellites to test for clonal identity between individuals and thus to draw conclusions about sexual and asexual modes of reproduction (Mueller and Wolfenbarger 1999; Kameyama and Ohara 2006; Majeský et al. 2012).

\section{Material and methods}

Sample collection and chemical analyses of groundwater

The study was conducted in eight edge Polish and three sub-central Belarusian populations of B. humilis (Table $\mathbf{1}$, Fig. 1). Each sampling locality was visited twice in 2012: in the spring to sample fresh leaves for DNA isolation and to count the flowers, and in the autumn to collect seeds (Table 2). In total, 254 individuals were analysed to determine the presence of female and male flowers; of those, 220 specimens were sampled for the genetic analyses, and 168 shrubs (all with seed coins) were used for the germination experiment. To minimize the probability of collecting vegetative ramets, the minimum distance between adjacent samples was $20 \mathrm{~m}$. Sample collection in Poland was approved by the Polish Ministry of the Environment (DOPpn-4102-873/41255/11/RS) as well as by the Regional Directors of Environmental Protection in Białystok (WPN.6202.15.27.2011.MW), Lublin (W P N.6205.60.2011.MO), Bydgoszcz (WPN.6402.1.16.2011.JC) and Gdańsk (RDOŚ-GdPNII.6402.1.80.2011.KD). Shrub birch was not classified as endangered in Belarus at the time of the study. The leaf material collected for DNA isolation was dried in silica gel and stored at room temperature. Seeds were collected in paper bags and also kept at room temperature.

For each population, six to 10 habitat plots were established during the spring and autumn to sample groundwater for chemical analyses, including $\mathrm{pH}$, electrical conductivity $\left(\mathrm{EC} ; \mu \mathrm{Sm} \cdot \mathrm{cm}^{-1}\right)$, the concentrations of $\mathrm{NH}_{4}{ }^{+}\left(\mathrm{mg} \cdot \mathrm{l}^{-1}\right)$ and $\mathrm{PO}_{4}{ }^{3-}\left(\mathrm{mg} \cdot \mathrm{l}^{-1}\right)$ ions, and groundwater level (Table 2). EC and $\mathrm{pH}$ were measured directly in the field using an EC-60 electrode and an EPS-1 electrode, respectively, which were connected to a CPC-401 pH-meter. The concentrations of $\mathrm{NH}_{4}{ }^{+}$and $\mathrm{PO}_{4}{ }^{3-}$ were determined through colourimetric analysis in the laboratory using the Phos Ver HACH reagent and the salicylate method, respectively. Based on Jabłońska's (2012) observations that $B$. humilis prefers water levels near the surface of the peat, the groundwater level in each sampling plot was assessed as either high (HWL; $\geq-10 \mathrm{~cm}$ ) or low (LWL; $\leq-10 \mathrm{~cm}$ ), and the degree of shading was arbitrarily estimated as no shade (no canopy cover), half shade (canopy cover of 50 $\%$ ) or full shade (canopy cover of $100 \%$ ).

\section{DNA laboratory analyses}

After homogenization of the leaf material in a TissueLyser LT bead mill (Qiagen), DNA was extracted with the AX Plant Kit (A\&A Biotechnology) according to the manufacturer's instructions, and the samples were then genotyped for AFLP markers. The AFLP procedure followed that of Vos et al. (1995) with some modifications suggested by Applied Biosystems (AFLP Plant Mapping Protocol). First, 33 primer pair combinations were tested on four individuals selected from the most distant populations, and the three primer combinations that resulted in the most polymorphic and repeatable fragments of homogenous intensity were chosen: EcoRI-ACC/MseI-CAC, EcoRI-ACC/MseI-CAT and EcoRI-AGC/MseI-CAC. The NED-labelled products of the selected amplifications were separated using an ABI PRISM 3130 (Applied Biosystems) instrument with a GeneScan 500 LIZ Size Standard (Applied Biosystems). AFLP profiles were scored for the 
Table 1 Names of sub-central (1-3) and edge (4-11) populations of $B$. humilis studied, their geographical locations, number of individuals sampled for genetic analyses, genetic diversity parameters (PLP - proportion of polymorphic fragments, $H-$ Nei's gene diversity) and inbreeding coefficients $\left(f_{\mathrm{AFLP}}\right)$.

\begin{tabular}{|c|c|c|c|c|c|c|c|c|}
\hline & \multirow[t]{2}{*}{ Population } & \multirow[t]{2}{*}{ Code } & \multicolumn{2}{|l|}{ Location } & \multirow{2}{*}{$\begin{array}{l}\text { No. of } \\
\text { inds. }\end{array}$} & \multirow[t]{2}{*}{ PLP } & \multirow[t]{2}{*}{$H \pm S E$} & \multirow[t]{2}{*}{$f_{\mathrm{AFLP}}$} \\
\hline & & & Latitude & Longitude & & & & \\
\hline 1. & Belarus, Ozero Borovoe & BOR & $52.83^{\prime} \mathrm{N}$ & $28.78^{\prime} \mathrm{E}$ & 21 & 33.3 & $0.096 \pm 0.010$ & -0.024 \\
\hline 2. & Belarus, Berezin'skij Zapovednik & $\mathrm{BZ}$ & $54.63^{\prime} \mathrm{N}$ & $28.35^{\prime} \mathrm{E}$ & 20 & 32.9 & $0.107 \pm 0.011$ & 0.024 \\
\hline 3. & Belarus, Sluck & SLU & $53.29^{\prime} \mathrm{N}$ & $27.63^{\prime} \mathrm{E}$ & 21 & 32.9 & $0.103 \pm 0.011$ & -0.028 \\
\hline 4. & Poland, Jezioro Mętne & $\mathrm{JM}$ & $53.79^{\prime} \mathrm{N}$ & $17.77^{\prime} \mathrm{E}$ & 20 & 31.1 & $0.101 \pm 0.011$ & 0.014 \\
\hline 5. & Poland, Magdzie Bagno & MB & $54.08^{\prime} \mathrm{N}$ & $23.16^{\prime} \mathrm{E}$ & 21 & 37.9 & $0.113 \pm 0.010$ & -0.006 \\
\hline 6. & Poland, Bagno Bubnów & $\mathrm{BB}$ & $51.22^{\prime} \mathrm{N}$ & $23.16^{\prime} \mathrm{E}$ & 21 & 36.5 & $0.114 \pm 0.011$ & 0.000 \\
\hline 7. & Poland, Torfowisko Sobowice & TS & $51.07^{\prime} \mathrm{N}$ & $23.23^{\prime} \mathrm{E}$ & 13 & 30.1 & $0.120 \pm 0.012$ & 0.012 \\
\hline 8. & Poland, Uroczysko Uściwierskie & UU & $51.21^{\prime} \mathrm{N}$ & $23.03^{\prime} \mathrm{E}$ & 21 & 36.1 & $0.110 \pm 0.011$ & 0.020 \\
\hline 9. & Poland, Łąki Ślesińskie & LS & $53.13^{\prime} \mathrm{N}$ & $17.70^{\prime} \mathrm{E}$ & 21 & 35.6 & $0.111 \pm 0.011$ & 0.014 \\
\hline 10. & Poland, Czerwone Bagno & $\mathrm{CB}$ & $53.62^{\prime} \mathrm{N}$ & $22.82^{\prime} \mathrm{E}$ & 20 & 35.2 & $0.108 \pm 0.011$ & 0.003 \\
\hline 11. & Poland, Szuszalewo & SUS & $53.73^{\prime} \mathrm{N}$ & $23.36^{\prime} \mathrm{E}$ & 21 & 36.5 & $0.108 \pm 0.010$ & 0.019 \\
\hline
\end{tabular}

presence or absence ( 1 or 0 , respectively) of bands between 70 and $500 \mathrm{bp}$ using GENEMAPPER 4.0 software (Applied Biosystems). To confirm the reproducibility of the AFLP fragments, two individuals from each population were replicated starting from the restriction/ligation reaction. The error rate was estimated as the percentage of different scores in comparison of $1 / 0$ matrices obtained for the duplicated samples (Bonin et al. 2004).

\section{Germination experiment}

From each of the individuals used to study seed quality, 100 seeds were selected and collectively weighed (wet mass) with an accuracy of $0.0001 \mathrm{~g}$. In total, 16,800 seeds were taken to the germination experiment. To break dormancy and increase the probability of germination, the seeds were kept at low temperatures from mid-November until the beginning of April: a total of
Fig. 1 Locations of edge Polish and sub-central Belarusian sampling sites of $B$. humilis. Population codes according to Table 1 . The grey area indicates the European range of the species.

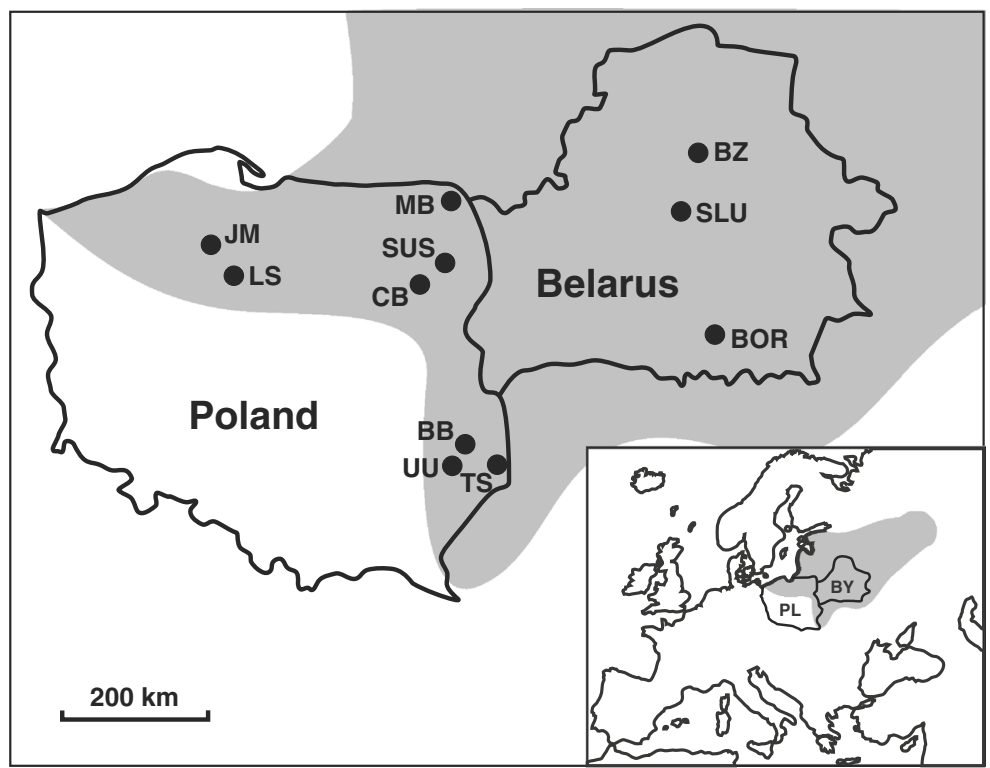




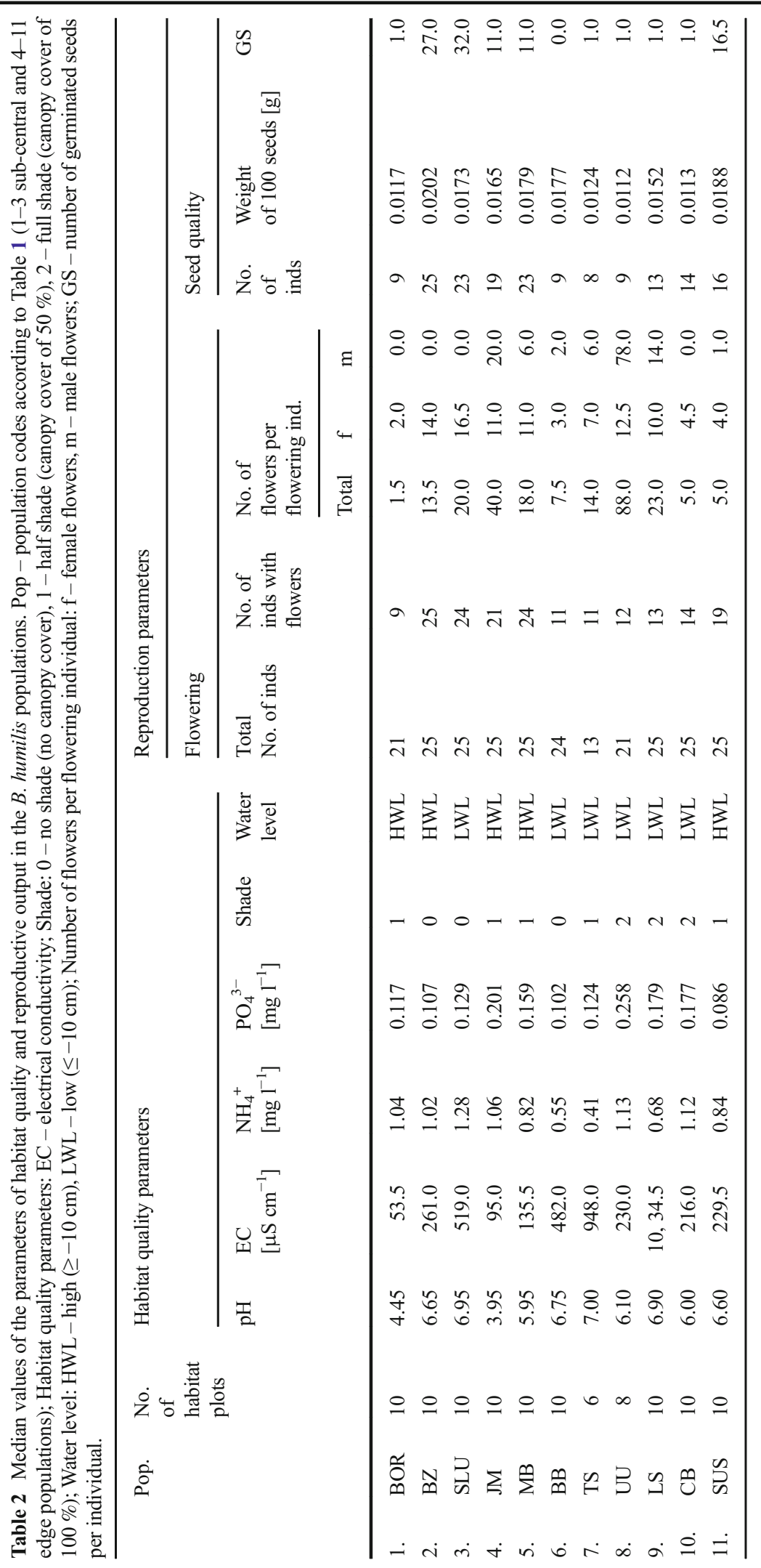


three months at $4^{\circ} \mathrm{C}$ and three weeks in February at $-20^{\circ} \mathrm{C}$. After vernalization, seeds were placed in closed Petri dishes on wet filter paper, and a germination test was conducted in a phytotron at the constant temperature of $20^{\circ} \mathrm{C}$ with a photoperiod of $10 \mathrm{hrs} \mathrm{light/14 \textrm {hrs }}$ dark (Holm 1994). Germinated seeds (those with visible radicles) were counted each day and removed, and the experiment was completed after 42 days, at which time no seed had germinated for five days (Holm 1994). During the test, distilled water was topped up regularly.

\section{Statistical analyses}

The AFLPdat R-script (Ehrich 2006) was run to check for the potential resampling of clones. For each population, allele frequencies were calculated using the Bayesian method with a non-uniform prior distribution of null allele frequencies and prior information on the level of inbreeding (Zhivotovsky 1999). Based on the allele frequencies, the proportion of polymorphic fragments (PLP) at the $5 \%$ level and Nei's gene diversity $(H)$ were estimated using AFLP-SURV version 1.0 (Vekemans 2002). To determine whether the intra-population genotypic variation of $B$. humilis was due to somatic mutations, which is the result of vegetative propagation, or recombination, which is associated with the sexual mode of reproduction, the cladistic approach of matrix incompatibility analysis was used (Mes 1998). For binary AFLP data, there are four possible combinations at two loci: $0 / 0,0 / 1,1 / 0$ and $1 / 1$, and the simplest explanation for the presence of all four combinations in a population is sexual reproduction. The presence of all possible combinations is referred to as 'incompatibility' of individual characters or individuals, because it is very unlikely that all these genotype profiles were produced via somatic mutations. As the incompatibility pattern is generated by recombination, it can be used as a measure of recombination when summed over all pairwise comparisons (Wilkinson 2001). The matrix incompatibility count (MIC) of the $B$. humilis populations was estimated with the help of the JACTAX jackknifing option in PICA version 4.0 (Wilkinson 2001). The MIC was tested with 1,000 permutations using the model of empirical frequencies, and the genotypes with the highest contributions to the MIC were consecutively removed from the total sample until the MIC was zero, which means that genotypes differing only by mutations were left in the matrix. The contribution of many genotypes in the incompatibility matrix is evidence of recent recombination events, and the sequential removal of the genotypes contributing the most to the matrix incompatibility statistics leads to a gradual decrease in the MIC whereas a sharp decline of MIC suggests that there are only a few recombinant genotypes contributing to the incompatibility (Gross et al. 2011).

The presence of loci under selection, i.e. 'outlier' loci that are extremely divergent from the rest of the genome (Luikart et al. 2003), can influence the level of inbreeding (Chybicki et al. 2011), so the hierarchical Bayesian method was performed to detect potential candidate loci using BayeScan software version 2.1 (Foll and Gaggiotti 2008). This method is based on a logistic regression model that divides genetic diversity into population- $(\beta)$ and locus-specific $(\alpha)$ components; a locus is assumed to be under selection when a locusspecific component is necessary to explain the observed pattern of variation. A positive $\alpha$ value implies diversifying selection, and a negative value may indicate balancing or purifying selection. To calculate a posterior probability for each locus, a reversible-jump Markov Chain Monte Carlo (MCMC) was applied to both models of selection in our dataset, and BayeScan was run by setting the sample size to 10,000 and the thinning interval to 50 (Foll and Gaggiotti 2008). Outliers were identified based on $\log$ (Bayes Factor) $>2$ and a corresponding posterior probability $>0.99$ (Foll and Gaggiotti 2008). Following the removal of outliers, the inbreeding coefficients $\left(f_{\text {AFLP }}\right)$ were calculated using the FAFLPcalc Excel macro (Dasmahapatra et al. 2007), which is available at http://www.ucl.ac.uk/ taxome/kanchon/\#publications.

To define the germination capacities of the populations, a median value of the number of germinated seeds per individual (GS) was determined for each locality (Table 2). A two-sample randomization test (test statistic - median difference; 10,000 randomizations) was used to equate the edge and sub-central localities in terms of seed mass, GS, the total number of flowers per flowering individual, and the numbers of female and male flowers per flowering individual. The same sexual reproduction parameters were also compared between the sampling sites with high and low water levels using the two-sample randomization test. A randomization one-way ANOVA (including post hoc tests and Holm's correction; test statistic - median difference; 10,000 randomizations) was carried out to compare seed mass, the total number of flowers per flowering individual, and the numbers of female and male flowers per 
flowering individual between populations subject to different degrees of shade (full shade, half shade and lack of shade). To determine which habitat factors $(\mathrm{pH}$, $\mathrm{EC}, \mathrm{NH}_{4}{ }^{+}, \mathrm{PO}_{4}{ }^{3-}$ ) were related to the production of inflorescences and seeds, randomized multiple linear regressions (10,000 randomizations) were performed, in which the reproductive efficiency parameters were used as the dependent variables, and the chemical parameters were the independent variables. Withinpopulation medians were used in the multiple regression analyses. Spearman's correlation coefficients were calculated to detect a monotonic relationship between the median values of seed mass and GS as well as between the genetic (PLP, $\mathrm{H}, f_{\mathrm{AFLP}}$ ) and reproductive (median values of the seed mass, the total number of flowers per flowering individual, and the numbers of female and male flowers per flowering individual) parameters. All of the calculations using the habitat and reproductive data were performed with Rundom Pro 3.14 software (Jadwiszczak 2009).

\section{Results}

The AFLP analysis included 229 polymorphic loci (70 from EcoR1-ACC/MseI-CAC, 73 from EcoR1-ACC/
$M s$ I-CAT and 86 from EcoR1-AGC/MseI-CAC). The error rate was $3.9 \%$. The proportion of polymorphic fragments (PLP) ranged from 30.1 in the Torfowisko Sobowice (TS) population to 37.9 in Magdzie Bagno (MB), which are both located in Poland (Table 1). The highest Nei's gene diversity value $(H)$ was in TS (0.120), and the lowest (0.096) was at the sub-central site, Ozero Borovoe (BOR). The compatibility analysis of each population indicated that most of the genotypic diversity was derived from sexual reproduction; all except 3-4 genotypes contributed to the matrix incompatibility (Fig. 2). The successive removal of the genotypes with the highest contributions generated a gradual decrease in the MIC. For example, in the BOR population (21 individuals studied), MIC reached zero after removing 17 genotypes from the total sample. This means that deleted genotypes contributed the most to the MIC, thus they were formed by recombination events. Only four genotypes in BOR were fully compatible, i.e. they arose as an effect of subsequent mutations. Of the polymorphic loci studied, five were likely under diversifying selection pressure. The inbreeding coefficients were very low in all of the populations $\left(f_{\mathrm{AFLP}}=-0.028\right.$ 0.024; Table 1).

Medians of the reproductive output parameters (the total number of flowers per flowering individual,

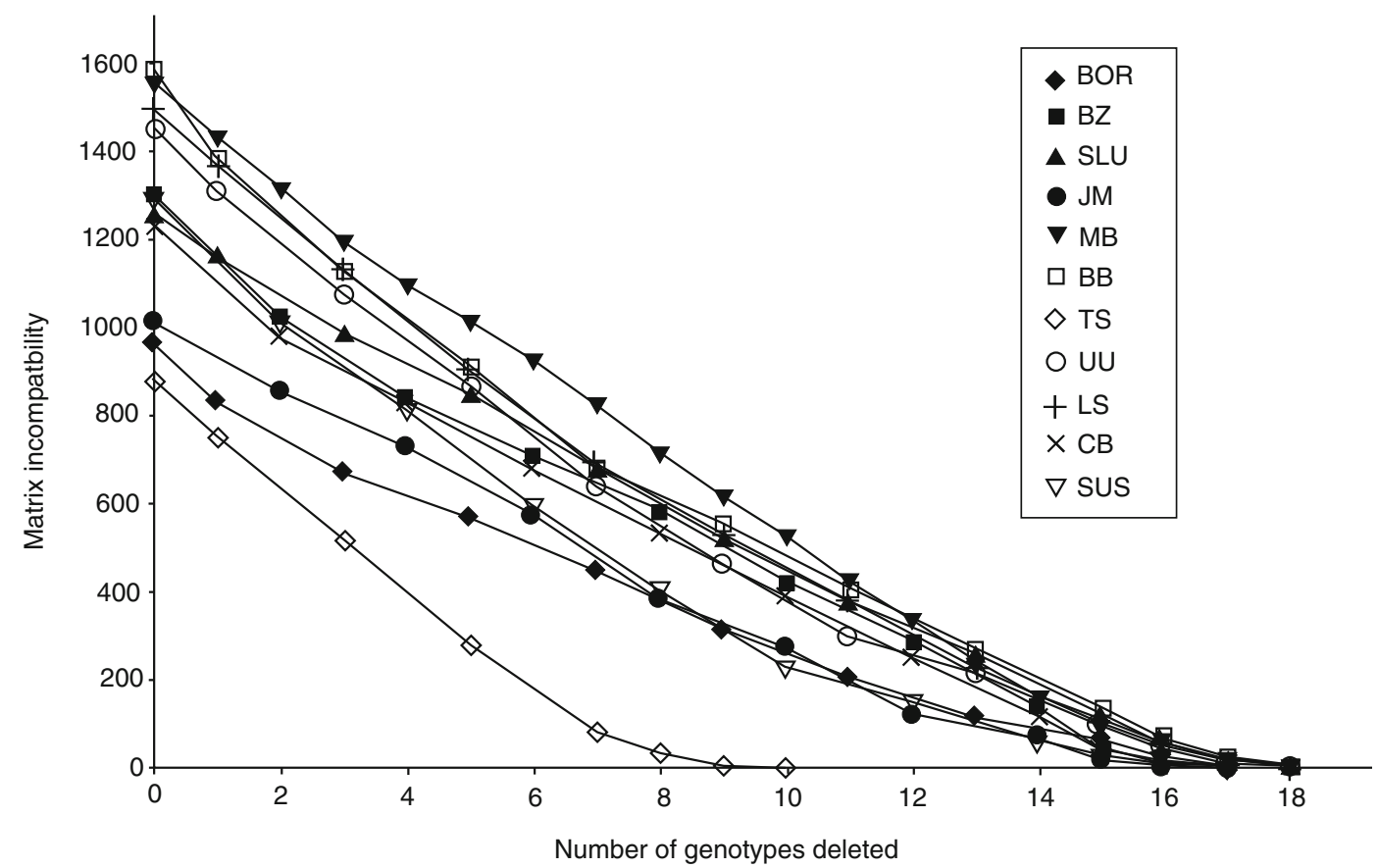

Fig. 2 Graph of character incompatibility. The reduction of the matrix incompatibility count (MIC) corresponds to the successive removal of genotypes from each of the populations studied. Graphic symbols refer to codes of populations described in Table 1. 
numbers of female and male flowers per flowering individual, seed mass and number of germinated seeds per individual) for all populations studied are presented in Table 2. The correlation analysis revealed a strongly significant and positive relationship between seed mass and germination capacity $\left(R_{\mathrm{S}}=0.573, P=0.000\right)$. There were no statistically significant differences in the total number of flowers per flowering individual, the numbers of female and male flowers per flowering individual and seed mass between edge and sub-central localities, but the number of germinated seeds was substantially higher in Belarus than in Poland (Table 3). None of the results of the Spearman's correlations between the genetic and reproductive parameters were significant (data not shown).

The median values of chemical parameters ( $\mathrm{pH}, \mathrm{EC}$, $\mathrm{NH}_{4}{ }^{+}, \mathrm{PO}_{4}{ }^{3-}$ ) of habitat quality as well as classification of the populations in respect of groundwater levels and shading are presented in Table 2 . The randomization tests revealed that the total number of flowers per flowering specimen and the numbers of male and female flowers per flowering specimen were not influenced by the water level (Table 3). However, seed mass and the number of germinated seeds were significantly higher in wet habitats compared to sites with low water levels.
Shading had a statistically significant impact on seed mass, the total number of flowers, and the numbers of female and male flowers per flowering specimen (Table 4). After applying Bonferroni's correction, no significant regression model was found among the four considered for the relationships between the chemical characteristics of the habitat and the reproduction output parameters (Table 5).

\section{Discussion}

The nuclear microsatellite analyses demonstrated that the genetic variation among the Betula humilis populations in the southwestern and sub-central parts of the species distribution was quite substantial and consistent with the patterns characteristic for outcrossed, windpollinated trees and shrubs (Jadwiszczak et al. 2011a,b). Although using the AFLP method, this study did not reveal high values of the genetic variation parameters (PLP $=30.1-37.9 ; H=0.096-0.120$ ) but confirmed that there was considerable genotypic diversity in the shrub birch at the study locations. Jadwiszczak et al. (2011b) hypothesized that the sexual breeding might explain the maintenance of substantial genetic
Table 3 Results of two-sample randomization tests comparing reproductive parameters (dependent variables) in high (HWL) vs low (LWL) water level habitats and in edge (EP) vs sub-central (SCP) populations (grouping variables).

*value significant after

Bonferroni's correction

\begin{tabular}{|c|c|c|c|c|}
\hline \multicolumn{3}{|l|}{ Variable } & \multirow{2}{*}{$\begin{array}{l}\text { Test } \\
\text { statistic }\end{array}$} & \multirow[t]{2}{*}{$P$} \\
\hline Grouping & Dependent & Medians & & \\
\hline \multirow[t]{5}{*}{ HWL vs LWL } & Seed mass & $\begin{array}{l}\mathrm{HWL}=0.0177 \\
\mathrm{LWL}=0.0140\end{array}$ & 0.0037 & $0.0014 *$ \\
\hline & Germinated seeds & $\begin{array}{l}\mathrm{HWL}=12.0000 \\
\mathrm{LWL}=2.0000\end{array}$ & 10.0000 & $0.0024 *$ \\
\hline & Total No. of flowers & $\begin{array}{l}\text { HWL }=13.0000 \\
\mathrm{LWL}=19.0000\end{array}$ & -6.0000 & 0.1791 \\
\hline & Female flowers & $\begin{array}{l}\mathrm{HWL}=2.0000 \\
\mathrm{LWL}=3.0000\end{array}$ & -1.0000 & 0.8845 \\
\hline & Male flowers & $\begin{array}{l}\mathrm{HWL}=8.0000 \\
\mathrm{LWL}=9.5000\end{array}$ & -1.5000 & 0.3966 \\
\hline \multirow[t]{5}{*}{ EP vs SCP } & Seed mass & $\begin{array}{l}\mathrm{EP}=0.0155 \\
\mathrm{SCP}=0.0175\end{array}$ & -0.0020 & 0.1278 \\
\hline & Germinated seeds & $\begin{array}{l}\mathrm{EP}=3.0000 \\
\mathrm{SCP}=22.0000\end{array}$ & -19.0000 & $0.0001 *$ \\
\hline & Total No. of flowers & $\begin{array}{l}\mathrm{EP}=14.0000 \\
\mathrm{SCP}=15.5000\end{array}$ & -1.5000 & 0.7457 \\
\hline & Female flowers & $\begin{array}{l}\mathrm{EP}=9.0000 \\
\mathrm{SCP}=11.0000\end{array}$ & -2.0000 & 0.5691 \\
\hline & Male flowers & $\begin{array}{l}\mathrm{EP}=4.0000 \\
\mathrm{SCP}=10.5000\end{array}$ & -6.5000 & 0.0853 \\
\hline
\end{tabular}


Table 4 Results of ANOVA comparing reproductive parameters in unshaded (0), half-shaded (1) and fully shaded (2) populations of $B$. humilis. $P_{\text {adj }}-P$ adjusted.

\begin{tabular}{|c|c|c|c|c|}
\hline Variable & d.f. & $F$ & $P$ & Post hoc tests \\
\hline Seed mass & 168 & 14.851 & $0.0001 *$ & $\begin{array}{l}0 \text { vs } 2, P_{\text {adj }}=0.0002 * \\
1 \text { vs } 2, P_{\text {adj }}=0.0003 * \\
0 \text { vs } 1, P_{\text {adj }}=0.0262 *\end{array}$ \\
\hline Total no. of flowers & 180 & 5.816 & $0.0039 *$ & $\begin{array}{l}1 \text { vs } 2, P_{\text {adj }}=0.0087 * \\
0 \text { vs } 2, P_{\text {adj }}=0.0164 *\end{array}$ \\
\hline No. of female flowers & 180 & 5.725 & $0.0037^{*}$ & 0 vs $1, P_{\text {adj }}=0.0015^{*}$ \\
\hline No. of male flowers & 180 & 11.400 & $0.0003 *$ & $\begin{array}{l}0 \text { vs } 2, P_{\text {adj }}=0.0003 * \\
0 \text { vs } 1, P_{\text {adj }}=0.0058 * \\
1 \text { vs } 2, P_{\text {adj }}=0.0098 *\end{array}$ \\
\hline
\end{tabular}

*value significant after Bonferroni's correction

a few genotypes causes a sharp decrease in the MIC to zero (Gross et al. 2011). The number of genotypes involved in the matrix incompatibility has been found to be higher in fertile populations, compared to the sterile ones, of the threatened shrub Grevillea rhizomatosa (Gross et al. 2011). In all of the $B$. humilis samples, the MIC reached zero when only 3-4 genotypes were left, which can mean that the effectiveness of recombination was similar among the

Table 5 Multiple regression analyses of habitat variables on the four parameters of reproductive output of $B$. humilis. All $P$ values are statistically non-significant after Bonferroni's correction.

\begin{tabular}{|c|c|c|c|c|c|c|c|c|}
\hline \multirow[t]{2}{*}{ Variable } & \multirow{2}{*}{$\begin{array}{l}\text { Coefficient } \\
B\end{array}$} & \multirow[t]{2}{*}{$t$} & \multirow[t]{2}{*}{$P$} & \multirow[t]{2}{*}{ Source } & \multicolumn{4}{|c|}{ ANOVA } \\
\hline & & & & & d.f. & $M S$ & $F$ & $P$ \\
\hline \multicolumn{9}{|c|}{ Seed mass $\left(N=11, R=0.578, R^{2}=0.000\right)$} \\
\hline $\mathrm{pH}$ & 0.0011 & 0.699 & 0.503 & \multirow{4}{*}{$\begin{array}{l}\text { regression } \\
\text { residual }\end{array}$} & 4 & 0.000009 & \multirow[t]{4}{*}{0.753} & \multirow[t]{4}{*}{0.595} \\
\hline $\mathrm{EC}$ & 0.0000 & -0.602 & 0.559 & & 6 & 0.000012 & & \\
\hline $\mathrm{NH}_{4}^{+}$ & 0.0001 & 0.012 & 0.990 & & & & & \\
\hline $\mathrm{PO}_{4}^{3-}$ & -0.0281 & -1.131 & 0.314 & & & & & \\
\hline \multicolumn{9}{|c|}{ Total number of flowers per flowering individual $\left(N=11, R=0.866, R^{2}=0.582\right)$} \\
\hline $\mathrm{pH}$ & 6.7190 & 0.946 & 0.382 & regression & 4 & 1132.183656 & \multirow[t]{4}{*}{4.489} & \multirow[t]{4}{*}{0.045} \\
\hline $\mathrm{EC}$ & -0.0153 & -0.604 & 0.623 & residual & 6 & 252.195744 & & \\
\hline $\mathrm{NH}_{4}^{+}$ & -3.4196 & -0.132 & 0.876 & & & & & \\
\hline $\mathrm{PO}_{4}^{3-}$ & 443.0175 & 3.883 & 0.011 & & & & & \\
\hline \multicolumn{9}{|c|}{ Number of female flowers per flowering individual $\left(N=11, R=0.683, R^{2}=0.111\right)$} \\
\hline $\mathrm{pH}$ & 1.489 & 0.728 & 0.490 & regression & 4 & 27.498312 & \multirow[t]{4}{*}{1.313} & \multirow[t]{4}{*}{0.366} \\
\hline $\mathrm{EC}$ & 0.004 & 0.616 & 0.548 & residual & 6 & 20.940519 & & \\
\hline $\mathrm{NH}_{4}^{+}$ & 11.672 & 1.568 & 0.168 & & & & & \\
\hline $\mathrm{PO}_{4}^{3-}$ & 25.772 & 0.784 & 0.479 & & & & & \\
\hline \multicolumn{9}{|c|}{ Number of male flowers per flowering individual $\left(N=11, R=0.872, R^{2}=0.599\right)$} \\
\hline $\mathrm{pH}$ & 7.474 & 1.103 & 0.287 & regression & 4 & 978.650639 & \multirow[t]{4}{*}{4.267} & \multirow[t]{4}{*}{0.026} \\
\hline $\mathrm{EC}$ & -0.024 & -0.975 & 0.420 & residual & 6 & 229.354120 & & \\
\hline $\mathrm{NH}_{4}^{+}$ & -16.799 & -0.682 & 0.431 & & & & & \\
\hline $\mathrm{PO}_{4}^{3-}$ & 431.557 & 3.967 & 0.008 & & & & & \\
\hline
\end{tabular}


endangered shrub birch populations regardless of their location within the species range. Moreover, our analyses demonstrated no statistically significant differences in seed mass, the total number of flowers, and the numbers of female and male flowers per flowering individual between edge and sub-central populations of shrub birch. The results obtained seem to be surprising because it has been suggested that fragmentation and loss of habitats forces plants to allocate more resources to asexual over sexual reproduction, as has been shown in the endangered shrub Haloragodendron lucasii (Sydes and Peakall 1998) and the disappearing population of B. humilis in northeastern Poland (Chrzanowska and Jadwiszczak 2015). Sexual reproduction was also found to be substantially reduced at marginal localities of the seaweed Fucus serratus (Viejo et al. 2011) and the pine Pinus strobus (Rajora et al. 2002) compared to centrally located populations. However, both groups of B. humilis localities were differentiated with respect to germination capacity (GS), which was significantly higher in sub-central samples compared to edge ones (test statistic $=-19.00, P=0.0001$ ). Out of the eight edge populations studied, the GS parameter was very low in five: Bagno Bubnów (BB), TS, Uroczysko Uściwierskie (UU), Łąki Ślesińskie (LS) and Czerwone Bagno (CB), where the median values of GS were not higher than 1.0. The greatest seed germination capacity was observed in the sub-central samples: 32 germinated seeds per specimen in the Sluck (SLU) and 27 in the Berezin'skij Zapovednik (BZ) populations. Although these results are rather average for birches (Holm 1994; Bodył 2006), they may mean that the sexual reproduction of $B$. humilis is more efficient in subcentral localities compared to edge ones. On the other hand, as the germination was tested in laboratory conditions, it is necessary to remember that this parameter of sexual output could be even worse in the natural environment, where the water scarcity, low temperature or granivore pressure can lower the pool of germinated seeds. Perala and Alm (1990) noticed that seed germination of four Betula species was generally best at about $20-30^{\circ} \mathrm{C}$, temperatures that are rather unusual in Poland and Belarus in early spring.

The small proportion of germinated seeds in some B. humilis samples could be a consequence of their low mass, as germination ability was positively correlated with seed mass $\left(R_{s}=0.573, P=0.000\right)$. Seed mass was also significantly correlated with the mean germination rate per population in $B$. pendula in northern Sweden
(Holm 1994). A low seed weight may result from the lack of an ovule because birches produce fruits even in the absence of pollination (Atkinson 1992), and in many angiosperm species, empty seeds can also be an effect of self-incompatibility or inbreeding (Wang 2003). Birches are generally recognized as self-incompatible plants (Atkinson 1992) because self-fertilization tests conducted with 31 trees belonging to nine species produced a relatively high proportion of viable seeds only in B. papyrifera and B. alleghaniensis (Clausen 1966). We believe that inbreeding is not responsible for the production of inviable seeds in $B$. humilis, because the inbreeding coefficient ( $\left.f_{\text {AFLP }}\right)$ values in the study populations were very low.

Low seed mass cannot be the only explanation for the poor germination at $B$. humilis sites because the seed weights in the populations SLU and MB were very similar and, at the same time, the number of sprouted seeds per individual was three times higher at SLU. The lack of a difference in the seed weights between the SLU and MB populations could be the result of infections by gall insects of the genus Semudobia in MB. Infected $B$. pendula seeds have been shown to be 4-5-fold heavier than healthy seeds (Tylkowski 2012), and gall midges have been responsible for the destruction of up to $18 \%$ of fertilized birch seeds (Atkinson 1992; Holm 1994). Although we did not notice any galls during the selection of seeds for the germination experiment, this explanation for the low number of sprouted seeds in the $B$. humilis populations cannot be excluded.

It is likely that germination of B. humilis seeds depends on the environmental conditions. We observed that $B$. humilis seeds were significantly heavier at sites with high water levels compared to populations in dry environments (median difference $=0.004, P=0.0014$ ). As heavier seeds showed better germination ability (median difference $=0.0, P=0.0024$ ), sprouting may be more successful in flooded environments. A germination experiment involving the tree Vitellaria paradoxa demonstrated that only the largest seeds in the population retained viability under conditions of water scarcity (Daws et al. 2004). Another habitat factor with a clear impact on the reproductive output of shrub birch was shading. An ANOVA revealed that seed mass decreased significantly in more shaded stands compared to sites with no canopy cover $(F=14.851, P=0.0001)$. Jadwiszczak et al. (2011b) noticed that shrub birches were taller and had a larger leaf surface area in shaded stands compared to shrubs inhabiting sites with open 
canopies. This could reflect a life strategy change. To increase fitness, it is likely that birches overgrown by competitive plants allocate more resources to growth and avoid investing in seed production.

However, the significant increase in the total number $(F=5.816, P=0.0039)$ and the numbers of female $(F=$ 5.725, $P=0.0037)$ and male $(F=11.400, P=0.0003)$ catkins per flowering individual at more shaded localities compared to unshaded populations seems to contradict the above hypothesis. Why do birches crowded by neighbouring vegetation invest limited resources into the production of flowers? One explanation is that the light-demanding birches start to flower before the canopy becomes too closed, as has been shown in Arabidopsis thaliana (Casal 2012). This assumption is questionable, because female birch catkins overwinter as primordia and appear at the time of bud burst, while male inflorescences develop between July and September, but pollen is released during the following spring (Holm 1994). This means that birch flowers are formed during the full growing season. A second possibility is that the excess of male flowers increases the chance of pollination in shaded habitats because pollen dispersal is related to plant height (Sakai and Sakai 2003). In our opinion, the abundance of male flowers is not just an effect of plant size, because all of the individuals we encountered in the $\mathrm{CB}$ population were very tall but almost without catkins. A third possibility is that shaded stands of B. humilis are, at the same time, rich in phosphorus. Studies conducted in Eurasian wetlands and grasslands have revealed that the investment of plants into sexual reproduction depends significantly on the stoichiometric relationship between nitrogen and phosphorus in the ground (Fujita et al. 2014). In areas with a high N:P ratio (P-limited), individuals start to flower later, have shorter flowering times, fewer seeds and smaller seed masses compared to plants in habitats with a low N:P ratio (N-limited). This is because sexual reproduction is P-consuming, so the abandonment of sexual propagation at $\mathrm{P}$-poor sites allows plants to move the limited resources into growth and defence against pathogens, which increases individual survival (Obeso 2002). However, phosphorus availability does not seem to be a factor responsible for the increase in flower production in shrub birches, because the regression model did not indicate significant relationship between $\mathrm{PO}_{4}{ }^{3-}$ concentrations and the total number of flowers per flowering individual $(F=4.489, P=0.045)$ after Bonferroni's correction. As all results of multiple regression models were non-significant after applying Bonferroni's correction, it might imply that chemical variables of habitat $\left(\mathrm{pH}, \mathrm{EC}, \mathrm{NH}_{4}{ }^{+}, \mathrm{PO}_{4}{ }^{3-}\right)$ had no influence on the reproductive output of $B$. humilis.

In summary, direct field observations strongly suggest that sexual reproduction in shrub birches can be impaired, especially in edge populations, so how can the pronounced genetic variation at endangered $B$. humilis localities be explained? In our opinion, there are three alternatives. First, birch seeds contain substantial amounts of phosphorus. It has been suggested that the successful recruitment of plants in P-impoverished habitats is due to the production of a few, phosphorus-rich seeds (Lambers et al. 2010). Phosphorus is a key mineral nutrient in every plant process that involves energy transfer, and developing seeds are the main source of phosphorus during plant growth. Lamont and Groom (2013) indicated that young plants developed from large, nutrient-enriched seeds were more protected against drought compared to seedlings sprouted from the smaller seeds. This is because the substantial amounts of phosphorus and nitrogen in large seeds play a critical role in photosynthesis, ensuring sufficient carbon delivery to the rapidly descending roots for effective drought-avoidance. However, supporting a hypothesis about relationship between seed weight and $\mathrm{PO}_{4}{ }^{3-}$ concentrations in $B$. humilis populations would require a more detailed analysis of birch grains. A second explanation is that sexual reproduction is very poor and reflects the current state of the populations, but the estimations of genetic diversity reflect past conditions because the studied genotypes arose some years ago. This supposition can be supported by the lack of significant correlations between genetic diversity and reproductive parameters. Jadwiszczak et al. (2011b) also suggested that the considerable degree of nuclear microsatellite diversity in $B$. humilis stands might be due to insufficient time for a decrease in genetic variation at the southwestern edge of the species' distribution. More than 600 years of the range fragmentation of Fagus sylvatica in the Iberian Peninsula resulted in decreased availability of pollen and increased levels of inbreeding and, in consequence, lowered reproduction of trees (Jump and Peñuelas 2006). A third possibility is that the genetic resources of endangered shrub birch populations are enriched by an inflow of genes from the congeners B. pendula and B. pubescens. Staszkiewicz et al. (1993) suggested that the morphological variation of the leaves, fruits and scales of B. humilis could have 
arisen from hybridization with common birches. Using cpDNA markers, Jadwiszczak et al. (2012a) demonstrated that sympatric populations of B. humilis, $B$. pendula and $B$. pubescens were genetically indistinguishable. Additionally, chromosome analysis conducted in the Polish populations of shrub birch revealed 19$60 \%$ of aneuploid individuals (Jadwiszczak et al. 2011c). Based on the presence of aneuploids in sympatric populations of $B$. pendula and $B$. pubescens (Helms and Jørgensen 1925; Hagman 1971), Jadwiszczak et al. (2011c) suggested that atypical karyotypes of some B. humilis specimens originated from interspecific crosses. However, testing the influence of interspecific gene exchange on the genetic diversity of $B$. humilis requires comparative studies of the nuclear genomes of conspecific birches.

Acknowledgments We thank P. Jadwiszczak and E. Jaworowska for their help in the field and laboratory. Funding for this work was provided by the National Science Centre, Poland (grant No. 2011/01/B/NZ8/01756). The authors wish to express their gratitude to the reviewers for their insightful, constructive comments on an earlier draft of the manuscript.

Open Access This article is distributed under the terms of the Creative Commons Attribution 4.0 International License (http:// creativecommons.org/licenses/by/4.0/), which permits unrestricted use, distribution, and reproduction in any medium, provided you give appropriate credit to the original author(s) and the source, provide a link to the Creative Commons license, and indicate if changes were made.

\section{References}

Alsos IG, Ehrich D, Thuiller W, Eidesen PB, Tribsch A, Schönswetter $P$ et al. (2012) Genetic consequences of climate change for northern plants. Proc Roy Soc Biol Sci Ser B 279: 2042-2051

Atkinson MD (1992) Betula pendula Roth (B. verrucosa Ehrh.) and B. pubescens Ehrh. J Ecol 80:837-870

Bodył M (2006) Zmienność żywotności nasion brzozy brodawkowatej (Betula pendula Roth) na terenie Polski w latach 1995-2004 [Seed viability variation of the silver birch (Betula pendula Roth) in Poland in 1995-2004)] Sylwan (Warsaw) 4:26-32 [in Polish with an English summary]

Bonin A, Bellemain E, Eidesen PB, Pompanon F, Brochmann C, Taberlet $P$ (2004) How to track and assess genotyping errors in population genetics studies. Mol Ecol 13:3261-3273

Calko VG (2014) Postanovlenie ministra prirodnyh resursov i ohrany okružaûŝej sredy Respubliki Belaruś 9 iûnâ 2014 No 26 (Resolution of the ministry of natural resources and environmental protection of the Republic of Belarus June 9, 2014 No 26). Available at: http:/gosinspekciya.gov.by/docs/ postanovlenie.pdf [in Russian]
Casal JJ (2012) Shade avoidance. The Arabidopsis Book 10:e157

Chrzanowska A, Jadwiszczak KA (2015) Disappearing population of Betula humilis Schrk. on the Maliszewskie Lake, NE Poland. Biodivers Res \& Conserv 37:23-27

Chybicki IJ, Oleksa A, Burczyk J (2011) Increased inbreeding and strong kinship structure in Taxus baccata estimated from both AFLP and SSR data. Heredity 107:589-600

Clausen KE (1966) Studies of incompatibility in Betula. Joint Proc. 2nd Genet. Workshop Soc. Amer. Foresters and Seventh Lake States Tree Improv. Conf. USDA Forest Serv Res Pap 6:48-52

Dasmahapatra KK, Lacy RC, Amos W (2007) Estimating levels of inbreeding using AFLP markers. Heredity 100:286-295

Daws MI, Gaméné CS, Glidewell SM, Pritchard HW (2004) Seed mass variation potentially masks a single critical water content in recalcitrant seeds. Seed Sci Res 14:185-195

De Witte LC, Armbruster GFJ, Gielly L, Taberlet P, Stöcklin J (2012) AFLP markers reveal high clonal diversity and extreme longevity in four key Arctic-alpine species. Mol Ecol 21:1081-1097

Ehrich D (2006) AFLPdat: a collection of R functions for convenient handling of AFLP data. Mol Ecol Notes 6:603-604

Foll M, Gaggiotti O (2008) A genome-scan method to identify selected loci appropriate for both dominant and codominant markers: A Bayesian perspective. Genetics 180:977-993

Fujita Y, Venterink HO, Van Bodegom PM, Douma JC, Heil GW, Hölzel N et al. (2014) Low investment in sexual reproduction threatens plants adapted to phosphorus limitation. Nature 505:82-86

Glémin S, Bazin E, Charlesworth D (2006) Impact of mating systems on patterns of sequence polymorphism in flowering plants. Proc R Soc Lond B Biol Sci 273:3011-3019

Gross CL, Nelson PA, Haddadchi A, Fatemi M (2011) Somatic mutations contribute to genotypic diversity in sterile and fertile populations of the threatened shrub, Grevillea rhizomatosa (Proteaceae). Ann Bot (Oxford) 109:331-342

Hagman M (1971) On self- and cross-incompatibility shown by Betula verrucosa Ehrh. and Betula pubescens Ehrh. Commun Inst Forest Fenniae 73:1-125

Hamrick JL, Godt MJW (1996) Effects of life history traits on genetic diversity in plant species. Philos Trans $R$ Soc Lond Ser B Biol Sci 351(1345):1291-1298

Helms A, Jørgensen CA (1925) Birkene paa Maglemose. Meglemose i grib skov undersøgelser over vegetationen paa en nordsjaellandsk mose udgivet. Bot Tidsskr 39:57-133

Hewitt GM (1999) Post-glacial re-colonization of European biota. Biol J Linn Soc 68:87-112

Holm S-O (1994) Reproductive patterns of Betula pendula and B. pubescens coll. along a regional altitudinal gradient in northern Sweden. Ecography 17:60-72

Jabłońska E (2006) Comparison of habitat conditions at Betula humilis sites in north-eastern and south-eastern Poland. Polish J Environm Stud 15(5d):181-187

Jabłońska E (2012) Vegetation with Betula humilis in Central Europe. Phytocoenologia 42:259-277

Jadwiszczak KA, Banaszek A, Chrzanowska A, Kłosowski S, Sozinov OV (2015a) The admixture zone of Betula humilis Schrk. phylogenetic lineages follows the eastern central European suture zone. Plant Ecol Divers 8:323-329

Jadwiszczak KA, Banaszek A, Jabłońska E, Sozinov OV (2011a) Could Betula humilis Schrk. have survived the last glaciation 
at a current margin of its distribution? - Testing the hypothesis of glacial refugium using nuclear microsatellites. Plant Syst Evol 297:147-156

Jadwiszczak KA, Banaszek A, Jabłońska E, Sozinov OV (2012a) Chloroplast DNA variation of Betula humilis Schrk. in Poland and Belarus. Tree Genet Genomes 8:1017-1030

Jadwiszczak KA, Drzymulska D, Banaszek A, Jadwiszczak P (2012b) Population history, genetic variation and conservation status of the endangered birch species Betula nana L. in Poland. Silva Fenn 4:465-477

Jadwiszczak KA, Jabłońska E, Banaszek A (2011b) Genetic diversity of the shrub birch Betula humilis Schrk. at the southwestern margin of its range. Plant Biosyst 145:893-900

Jadwiszczak KA, Jabłońska E, Kłosowski S, Banaszek A (2011c) Aneuploids in the shrub birch Betula humilis populations in Poland. Acta Soc Bot Poloniae 80:233-235

Jadwiszczak KA, Jabłońska E, Kłosowski S, Banaszek A (2015b) Genetic variation and habitat conditions in Betula humilis Schrk. populations in Poland, Belarus and Latvia. Plant Biosyst 149:433-441

Jadwiszczak P (2009) Rundom Pro 3.14. Software for classical and computer-intensive statistics. Available at: http://pjadw. tripod.com

Joppa LN, Visconti P, Jenkins CN, Pimm SL (2013) Achieving the Convention on Biological Diversity's goals for plant conservation. Science 341:1100-1103

Jump AS, Hunt JM, Martínez-Izquierdo JA, Peñuelas J (2006) Natural selection and climate change: temperature-linked spatial and temporal trends in gene frequency in Fagus sylvatica. Mol Ecol 15:3469-3480

Jump AS, Peñuelas J (2006) Genetic effects of chronic habitat fragmentation in a wind-pollinated tree. Proc Natl Acad Sci USA 103:8096-8100

Kameyama Y, Ohara M (2006) Predominance of clonal reproduction, but recombinant origins of new genotypes in the freefloating aquatic bladderwort Utricularia australis $\mathrm{f}$. tenuicaulis (Lentibulariaceae). J Plant Res 119:357-362

Lambers H, Brundrett MC, Raven JA, Hopper SD (2010) Plant mineral nutrition in ancient landscapes: high plant species diversity on infertile soils is linked to functional diversity for nutritional strategies. Plant Soil 334:11-31

Lamont BB, Groom PK (2013) Seeds as a source of carbon, nitrogen, and phosphorus for seedling establishment in temperate regions: A synthesis. Am J Plant Sci 4:30-40

Luikart G, England PR, Tallmon D, Jordan S, Taberlet P (2003) The power and promise of population genomics: from genotyping to genome typing. Nat Rev Genet 4:981-994

Majeský L, Vašut RJ, Kitner M, Trávníček B (2012) The pattern of genetic variability in apomictic clones of Taraxacum officinale indicates the alternation of asexual and sexual histories of apomicts. PLOS ONE 7(8):e41868

Mes THM (1998) Character compatibility of molecular markers to distinguish asexual and sexual reproduction. Mol Ecol 7: $1719-1727$

Mitton JB, Duran KL (2004) Genetic variation in piñon pine, Pinus edulis, associated with summer precipitation. Mol Ecol 13:1259-1264

Mueller UG, Wolfenbarger LL (1999) AFLP genotyping and fingerprinting. Trends Ecol Evol 14:389-394
Nagamitsu T, Kawahara T, Kanazashi A (2006) Pollen-limited production of viable seeds in an endemic dwarf birch, Betula apoiensis, and incomplete reproductive barriers to a sympatric congener, B. ermanii. Biol Conserv 129:91-99

Neel MC, Ross-Ibarra J, Ellstrand NC (2001) Implications of mating patterns for conservation of the endangered plant Eriogonum ovalifolium var. vineum (Polygonaceae). Am J Bot 88:1214-1222

Obeso JR (2002) The costs of reproduction in plants. New Phytol 155:321-348

Perala DA, Alm AA (1990) Reproductive ecology of birch: A review. Forest Ecol Managem 32:1-38

Petit RJ, Aguinagalde I, de Beaulieu J-L, Bittkau C, Brewer S, Cheddadi R et al. (2003) Glacial refugia: hotspots but not melting pots of genetic diversity. Science 300:15631565

Rajora OP, Mosseler A, Major JE (2002) Mating system and reproductive fitness traits of eastern white pine (Pinus strobus) in large, central versus small, isolated, marginal populations. Can J Botany 80:1173-1184

Rao VR, Hodgkin T (2002) Genetic diversity and conservation and utilization of plant genetic resources. Plant Cell Tiss Org 68:1-19

Sakai A, Sakai S (2003) Size-dependent ESS sex allocation in windpollinated cosexual plants: fecundity vs. stature effects. $J$ Theor Biol 222:283-295

Staszkiewicz J, Białobrzeska M, Truchanowicz J, Wójcicki JJ (1993) Variability of Betula humilis (Betulaceae) in Poland. IV. Hybrid and introgressive forms. Fragm Florist Geobot 38:475-488

Sydes MA, Peakall R (1998) Extensive clonality in the endangered shrub Haloragodendron lucasii (Haloragaceae) revealed by allozymes and RAPDs. Mol Ecol 7:87-93

Tylkowski T (2012) Betula pendula seed storage and sowing pretreatment: effect on germination and seedling emergence in container cultivation. Dendrobiology 67:49-58

Vekemans X (2002) AFLP-SURV. Version 1.0. Distributed by the author, Laboratoire Génétique et Ecologie Végétale, Université Libre de Bruxelles, Belgium

Viejo RM, Martínez B, Arrontes J, Astudillo C, Hernández L (2011) Reproductive patterns in central and marginal populations of a large brown seaweed: drastic changes at the southern range limit. Ecogeography 34:75-84

Vos P, Hoger R, Bleeker M, Reijans M, van de Lee T, Horne M et al. (1995) AFLP: a new technique for DNA fingerprinting. Nucl Acids Res 23:4407-4414

Wang KS (2003) Relationship between empty seed and genetic factors in European beech (Fagus sylvatica L.). Silva Fenn 37(4):419-428

Wilkinson M (2001) PICA 4.0: Software and documentation. Department of Zoology, The Natural History Museum, London

Załuski T, Jabłońska E, Pawlikowski P, Pisarek W, Kucharczyk M (2014) Betula humilis Schrank. In Kaźmierczakowa R, Zarzycki K, Mirek Z (eds) Polska czerwona księa roślin (Polish plant red book). W. Szafer Institute of Botany, Polish Academy of Sciences, Kraków, pp 92-95

Zhivotovsky LA (1999) Estimating population structure in diploids with multilocus dominant DNA markers. Mol Ecol 8: 907-913 